\title{
Communicating CSR in High Profile Industries: Case Study of Czech Chemical Industry
}

\section{Libena Tetrevova}

\author{
University of Pardubice \\ Studentska 95, 53210 Pardubice, Czech Republic \\ E-mail. libena.tetrevova@upce.cz
}

cross $^{\text {ref }}$ http://dx.doi.org/10.5755/j01.ee.29.4.19199

\begin{abstract}
The paper deals with the issue of web communication of Corporate Social Responsibility (CSR) activities by companies of high profile industries, specifically by the chemical industry enterprises operating in the Czech Republic. Based on the content analysis of the websites of companies in the Association of Chemical Industry of the Czech Republic, employing 60 percent of workers and generating more than 70 percent of the production of this industry, it analyses and evaluates the level of CSR communication of these companies in economic, social, environmental, ethical and philanthropic areas. The study shows that the level of communication of CSR activities of chemical companies in the Czech Republic is low and corresponds to the low level of CSR communication in this country. Chemical industry companies mostly communicate activities falling within the sphere of economic and environmental responsibility, completely neglecting activities of ethical responsibility. In all areas of CSR, large corporations communicate a larger range of activities than small and medium enterprises, with no significant difference in communication between national and foreign companies. Thus, it is necessary to adopt the set of measures proposed in the paper, both at the governmental level and at the level of individual enterprises.
\end{abstract}

Keywords: Corporate Social Responsibility; CSR Communication; High Profile Industries; Chemical Industry; Chemical Companies; Size of Enterprises; Ownership of Enterprises; Environmental Responsibility.

\section{Introduction}

The phenomenon linking the economic and social aspects of entrepreneurship "in today's socially conscious market environment" (Du et al., 2010, p. 8) is the application of the Corporate Social Responsibility (CSR) concept. CSR is "a social process where communication has a central role" (Golob et al., 2013, p. 177). Efficient CSR communication is a prerequisite for sharing benefits associated with the application of this concept not only by corporate stakeholders and society as a whole, but also by the very companies that develop socially responsible activities. However, the topic of CSR communication is a relatively new topic, which has been paid attention to in the present millennium. As Golob et al. (2013) point out with reference to Nielsen and Thomsen (2009) and Ihlen et al. (2014), this issue has not yet been given sufficient attention, both in theory and practice.

The present study is thus a response to two fundamental, closely related problems. The first is the low level of knowledge in the area of CSR communication and the consequent need to increase this level, which is a task of the academic sphere within the fulfilment of the second academic mission (Laredo, 2007; Montesinos et al., 2008). The fact is that, a number of companies operate in practice carrying out interesting and beneficial CSR activities, but they do not inform the public about these activities at all, or inform inadequately (van Wensen et al., 2011). One of the main reasons is the lack of knowledge about CSR communication and the related problem of defining key topics and indicators to be communicated (Arnold, 2008; van Wensen et al., 2011). Others include doubts about the advantage of CSR communication, fears of misuse of sensitive information or high costs of CSR communication (Kolk, 2010; van Wensen et al., 2011; Vlckova, 2011). An interesting object of exploration in the context of knowledge base is represented by companies of high profile (Hackston \& Milne, 1996; Roberts, 1992) or socially sensitive (Brammer \& Millington, 2004; Hoejmose et al., 2013; Kostalova \& Tetrevova, 2017) industries. These are companies that face unique social pressures (Roberts, 1992). These industries include, for example, chemical, metallurgical, arms, tobacco and gaming industries (Roberts, 1992; Tetrevova et al., 2017). For companies in these industries, developing and communicating socially responsible activities is crucial. Thus, they can represent a valuable source of knowledge and provide examples of good practice.

The other, complementary problem is the generally low level of CSR communication achieved by companies in a number of countries, especially post-communist countries (see more in KPMG, 2015). This issue is also highlighted by, among others, competent EU authorities which declare the need to increase transparency in the communication of socially responsible activities of companies, see more e.g. in COM(2011)206, COM(2011)681 or Directive 2014/95/EU. Therefore, it seems expedient to undertake a deeper examination of CSR communication in individual countries, especially post-communist countries, with regard to individual industries. In fact, it is necessary to encourage a wider debate on the level of CSR communication in individual countries and industries as well as on measures to 
increase this level. The purpose of this article is to contribute to the discussion of these topics, initiate adequate changes and, at the same time, expand the knowledge base in this area.

Taking into account the specific conditions in one of the post-communist countries, the Czech Republic, the following specific objective was set in order to fulfil the stated intention: to analyse and evaluate the level of web communication of CSR activities by the selected high profile industry companies, namely by chemical industry companies operating in the Czech Republic, and formulate recommendations to increase this level. Attention will be focused on the web communication of CSR, which is a modern way of communication, the main advantages of which are the public accessibility of information and the possibility of easy and quick updating of the presented information. The presented study is based on a mixed type research combining advantages of qualitative and quantitative research. The applied methods included both content analysis, and the general research methods.

\section{Literature Review and Hypotheses}

Various areas and activities may be subject to CSR communication. Literature provides a number of alternative approaches to their definition and specification. In the classic conception, the CSR areas consist of the so called 3P: Profit (economic responsibility), People (social responsibility) and Planet (environmental responsibility) (Edgeman \& Eskildsen, 2012; Jurisova \& Durkova, 2012; Mulyadi \& Anwar, 2012; van Marrewijk \& Werre, 2003). Tamm et al. (2010) distinguish the area of internal social responsibility, which focuses on employee well-being, and the area of external social responsibility, which is targeted at other stakeholders. According to Carroll (1979; 1999), CSR includes economic, legal, ethical and discretionary (philanthropic) responsibilities. A comprehensive approach to defining CSR areas, based on the above-mentioned concepts, is offered by Tetrevova (2011). She distinguishes five responsibilities: economic, social, environmental, ethical and philanthropic.

Specification of particular CSR activities was dealt with both by the above authors and many others, e.g. (Levy \& Park, 2011; Maignan \& Ferrell, 2004; Peloza \& Shang, 2011). With regard to the communication thereof, they are specified by international reporting schemes, e.g. Global Reporting Initiative (GRI, 2013), ISO 26000 (ISO, 2010), or OECD Guidelines for Multinational Enterprises (OECD, 2011), but also by individual authors (e.g. Birth et al., 2008; Esrock \& Leichty, 1998; Chambers et al., 2003).

The level of communication of these activities varies widely across countries and industries, as shown by a survey carried out by KPMG in 2015 using a sample of 4,500 firms (the 100 largest companies operating in 15 industry sectors in each of the 45 selected countries of the world). Based on an analysis of publicly available information in annual financial reports, standalone CSR reports and on company websites, it was found that around 73 percent of companies worldwide reported about CSR and $2 / 3$ countries had a higher than average reporting rate. Significantly lower levels of CSR communication are achieved in post-communist countries. Of the seven post- communist countries included in this survey, only Hungary was above the average, ranking 14th. The remaining six post-communist countries have lower-than-average reporting rates. Romania ranked 32nd, Russia 33rd, Poland 36th, Slovakia 38th, the Czech Republic 40th and Kazakhstan 45th. As far as industry sectors are concerned, the highest global rates of CSR reporting are achieved by metallurgical companies, while chemical companies ranked 9th. (KPMG, 2015) Therefore, the basic research question is what is the level of CSR communication of chemical companies operating in the Czech Republic. In view of the above, the hypothesis $\mathrm{H} 1$ can be formulated: The level of CSR communication of chemical companies operating in the Czech Republic is low.

Another research question is also how the level of CSR communication differs from the point of view of individual CSR areas. In general, the level of communication of CSR activities varies from one sector to another, depending on the industry focus. There is a logical link between implemented and communicated CSR activities and core corporate activities (Du et al., 2010; Konrad et al., 2006). Thus, in the case of chemical companies whose social sensitivity stems mainly from the risk of negative environmental impacts, special attention can be expected to be given to communicating environmentally responsible activities. This is evidenced, for example, by Gamerschlag et al. (2011), Graafland et al. (2002), Reverte (2008) or Tagesson et al. (2009). Thus, we can formulate the $\mathrm{H} 2$ hypothesis: Companies in the chemical industry operating in the Czech Republic pay increased attention to the communication of CSR activities in the environmental sphere.

Another research question is whether this level is different in terms of the size or ownership of companies. The broader view is that it is large companies and multinational corporations that have better economic conditions for applying and reporting socially responsible behaviour, as compared to small and medium sized enterprises (SMEs) (Baumann-Pauly et al., 2013; Graafland et al., 2003; Knudsen, 2011; McWilliams \& Siegel, 2001; Mousiolis et al., 2015; Pedersen, 2009). As stated by McWilliams and Siegel (2001, p. 123), "when scale economies exist, large firms will have lower average costs for providing CSR attributes than small firms". Baumann-Pauly et al. (2013, p. 24) then add "small firms probably strive to strengthen the relationships with their most important stakeholders and thereby focus their CSR communication on selected parties such as industry networks, rather than the general public". The low level of CSR communication among SMEs is confirmed by, for example, Dincer and Dincer (2010) or Nielsen and Thomsen (2009). Higher levels of CSR communication in large companies are documented by, for example (Gamerschlag et al., 2011; Gray, 2007; Knox et al., 2005; Tagesson et al., 2009). As far as the ownership of companies is concerned, it has been documented that the range of activities communicated by public companies is larger than that communicated by private firms (e.g. Darus et al., 2009; Said et al., 2009; Tagesson et al., 2009). From the point of view of private companies, we can meet both the above-mentioned claims about the higher level of CSR communication of multinational corporations and the 
denial thereof. Chapple and Moon (2005) and Line and Braun (2007) state that the extent of CSR activities communicated by multinational companies on foreign markets does not correspond to the range of activities communicated in the country of origin of these enterprises. The level of communication corresponds to the customs of the countries in which they operate and the degree of development of civil society in these countries (Chapple \& Moon, 2005; Line \& Braun, 2007). Thus, we can formulate the following two hypotheses: $\mathrm{H} 3$ : The range of CSR activities communicated by large chemical companies operating in the Czech Republic is higher compared to the range of activities of communicated by SMEs. H4: The range of CSR activities communicated by private foreigncontrolled chemical companies operating in the Czech Republic is higher than the range of activities communicated by private national companies.

\section{Data and Methodology}

The level of CSR communication of chemical companies operating in the Czech Republic was assessed on the basis of a content analysis of their websites. The technique of content analysis had been chosen because it represents a flexible, systematic and objective means of describing phenomena (Elo et al., 2014; Elo \& Kyngas, 2008; Krippendorff, 2004; Schreier, 2012). The communication channel in the form of corporate websites had been chosen in view of the fact that web-based CSR communication is used by all companies with few exceptions, and, moreover, they are a publicly available source of information. Both of these facts can be considered an advantage over CSR communication channels in the form of CSR reports or annual reports. Moreover, the effectiveness of using this method has been confirmed by a number of researchers, e.g. (Aramayo Garcia et al., 2016; Branco \& Rodrigues, 2008; Capriotti \& Moreno 2007; Chaudhri \& Wang, 2007; Dincer \& Dincer, 2010; Jelinkova et al., 2016; KPMG, 2015; Said et al., 2009; Takano, 2013).

The content analysis focused on communicated activities in a modified concept of five CSR areas; see more in (Tetrevova, 2011). Based on the literature review and practical experience with CSR communication, specific assessed activities were identified. The basis for their determination was a review of CSR activities recommended by Tetrevova et al. (2017) for implementation to companies of high profile industries. We can describe the methodology with respect to the monitored CSR areas as a method of communicating economic, social, environmental, ethical and philanthropic activities. The communication of $10 \mathrm{CSR}$ activities in the area of economic responsibility, 11 activities in the area of social responsibility, 8 activities in the area of environmental responsibility, 8 activities in the area of ethical responsibility and 5 CSR activities in the area of philanthropic responsibility were assessed. An overview of the 42 activities assessed is given in Table 1.

From January to March 2017, we ed the content of the websites of manufacturing companies associated as of January 1, 2017 in the Association of Chemical Industry of the Czech Republic. This association brings together a significant number of chemical companies in the Czech
Republic, employing 60 percent of workers and generating more than 70 percent of chemical industry output. As of that date, the Association comprised 56 manufacturing chemical companies. However, one of these companies did not have a functional website and was therefore not included in the study. The monitored companies are included in the chemical industry in a broader sense; they are part of the Divisions 19.2 (Manufacture of refined petroleum products), 20 (Manufacture of chemicals and chemical products), 21 (Manufacture of basic pharmaceutical products and pharmaceutical preparations) and 22 (Manufacture of rubber and plastic products) according to the NACE Rev. 2 classification.

Table 1

Method of Communicating Economic, Social, Environmental, Ethical and Philanthropic Activities - CSR Activities Assessed

\begin{tabular}{|c|c|}
\hline & onomic responsibility activities assessed \\
\hline & Good governance practices \\
\hline 2 & Product quality care and product safety \\
\hline 3 & Creation and implementation of product innovations \\
\hline 4 & Strengthening of customer relations \\
\hline 5 & Strengthening of relations with owners and investors \\
\hline 6 & Strengthening of relations with suppliers and purchasers \\
\hline 7 & Development of relationships with public institutions \\
\hline 8 & Partnerships with professional associations \\
\hline & Partnerships with educational institutions \\
\hline & Development of public relations \\
\hline & cial responsibility activities assessed \\
\hline 1 & Ensuring health and safety at work \\
\hline 2 & Providing a quality work environment \\
\hline 3 & Educating and developing staff \\
\hline 4 & Applying measures to eliminate discrimination in employment \\
\hline 5 & $\begin{array}{l}\text { Ensuring freedom of association in trade unions and the right to } \\
\text { collective bargaining }\end{array}$ \\
\hline 6 & $\begin{array}{l}\text { Implementation of a quality process of recruitment and termination } \\
\text { of employment }\end{array}$ \\
\hline 7 & Employee involvement in the decision-making process \\
\hline 8 & Employee care \\
\hline 9 & Ensuring work-life balance \\
\hline & Combating mobbing and harassment \\
\hline & Ensuring a healthy corporate culture \\
\hline & vironmental responsibility activities assessed \\
\hline & Ensuring compliance with environmental legislation \\
\hline 2 & Saving energy and other resources \\
\hline 3 & Minimizing waste and promoting recycling \\
\hline 4 & Safe handling of hazardous substances \\
\hline 5 & Application of best available techniques \\
\hline 6 & Supporting resource conservation and biodiversity \\
\hline 7 & Preventing and correcting negative environmental impacts \\
\hline & $\begin{array}{l}\text { Encouraging initiatives to promote a responsible approach to the } \\
\text { environment }\end{array}$ \\
\hline & ical responsibility activities assessed \\
\hline & Installation of a code of ethics \\
\hline 2 & Education and training of employees in terms of ethical conduct \\
\hline 3 & Ethical reporting \\
\hline 4 & Ethical audit \\
\hline 5 & Application of ethical heroes \\
\hline 6 & Creation of a corporate ombudsman's office \\
\hline 7 & Creation of an ethics committee \\
\hline 8 & Line established for reporting unethical behaviour \\
\hline & lanthropic responsibility activities assessed \\
\hline & Corporate giving, incl. corporate sponsorship \\
\hline 2 & Support for donor activities of employees \\
\hline 3 & Corporate volunteering \\
\hline 4 & Support for individual employee volunteering \\
\hline & Cooperation with non-profit organizations \\
\hline
\end{tabular}


The ARES database of the Ministry of Finance of the Czech Republic was used to identify the size category and the form of ownership of the monitored companies. The distinction of size categories was established on the basis of the Commission Recommendation of 6 May 2003 concerning the definition of micro, small and mediumsized enterprises. The distinction of the form of ownership was made in accordance with Regulation (EU) No. $549 / 2013$ of the European Parliament and of the Council of 21 May 2013 on the European system of national and regional accounts in the European Union (so-called ESA 2010). The study ed the content of websites of 9 small, 25 medium and 21 large enterprises. These were websites of 2 public non-financial corporations, 26 private non-financial corporations (national) and 27 private non-financial corporations (foreign-controlled). The data obtained were processed using MS Excel statistical tools. The tools of descriptive statistics were applied.

\section{Results and Discussion}

The survey shows that 40 percent of the monitored chemical companies operating in the Czech Republic offer a CSR or sustainable development category within the main menu of their websites. Almost a third of the companies make annual reports available on their websites, which also contain selected information about CSR activities being developed. Three companies also release their CSR reports.

The extent, to which the CSR activities defined above are communicated by the chemical companies, is shown in Table 2. It also shows differences in the extent of reported CSR activities from the point of view of companies with different forms of ownership.

Communicating CSR Activities - Specification in Terms of the Ownership of the Companies

\begin{tabular}{|l|c|c|c|c|c|c|c|c|}
\hline \multicolumn{1}{|c|}{ Type of firms } & Min & Max & Mean & Median & Mode & Std. Dev. & Skewness & Kurtosis \\
\hline Public & 15 & 30 & 22.50 & 22.5 & NA & 7.50 & NA & NA \\
\hline Private (national) & 1 & 35 & 16.35 & 16 & 16 & 7.47 & 0.47 \\
\hline Private (foreign controlled) & 3 & 29 & 14.89 & 14 & 11 & 0.49 \\
\hline All firms & 1 & 35 & 15.85 & 15 & 16 & 0.70 & 0.37 & 0.32 \\
\hline
\end{tabular}

Table 2 shows that the monitored chemical companies most often communicate 16 of the 42 CSR activities surveyed. More than half of the companies communicate at least 15 activities. As far as the ownership-based differentiation is concerned, a greater number of communicated activities are reported by the public corporations than the private ones. But we need to take into account the fact that only two public corporations were included in the sample of companies. As for the difference between national and foreign-controlled corporations, a slightly smaller number of communicated activities are reported by foreign-controlled corporations. This difference is evident especially in the environmental area and also in the social area. This is confirmed the findings of Chapple and Moon (2005) and Line and Braun (2007). The differences in the range of CSR activities communicated in terms of the company size are apparent from Table 3.

Table 3

Communicating CSR Activities - Specification in Terms of the Size of the Companies

\begin{tabular}{|l|c|c|c|c|c|c|c|c|}
\hline \multicolumn{1}{|c|}{ Type of firms } & Min & Max & Mean & Median & Mode & Std. Dev. & Skewness & Kurtosis \\
\hline Small & 1 & 29 & 13.56 & 13 & 11 & 7.27 & 0.59 \\
\hline Medium & 3 & 35 & 14.48 & 14 & 16 & 7.08 & 1.76 \\
\hline Large & 10 & 30 & 18.48 & 18 & 16 & 5.31 & 0.46 \\
\hline
\end{tabular}

It is clear from Table 4 that the number of CSR activities communicated by chemical companies is growing with the size category of these companies. This confirms previously published findings about a larger range of information presented by large companies. More than half of the monitored large chemical companies operating in the Czech Republic communicate at least 18 CSR activities assessed. As for medium-sized businesses, there are only 14 activities communicated, and as for small businesses there are 13 activities communicated.
We can also e and evaluate differences from the point of view of individual CSR areas. In view of the fact that greater differences in the range of communication have been demonstrated from the point of view of the size of the companies than from the point of view of the form of ownership, we will make a more detailed specification based on this criterion. For more details see Table $4-$ Table 9.

Communicating Economic Responsibility Activities

Table 4

\begin{tabular}{|l|c|c|c|c|c|c|c|c|}
\hline \multicolumn{1}{|c|}{ Type of firms } & Min & Max & Mean & Median & Mode & Std. Dev. & Skewness & Kurtosis \\
\hline Small & 1 & 10 & 5.11 & 5 & 5 & 2.23 & 0.56 & 2.76 \\
\hline Medium & 2 & 10 & 5.52 & 6 & 6 & 1.98 & 0.46 & 0.52 \\
\hline Large & 3 & 10 & 7.05 & 7 & 8 & 1.73 & -0.26 & -0.02 \\
\hline All firms & 1 & 10 & 6.04 & 6 & 6 & 2.10 & 0.06 & -0.12 \\
\hline
\end{tabular}

As shown in Table 4, communication in the area of economic responsibility can be assessed relatively positively. The monitored chemical companies most often communicate 6 out of 10 activities assessed. The number of activities communicated increases with the size category of the companies. From the point of view of specific activities, the strengthening of customer relationships (96 percent of the companies) and the care of product quality 
and safety (95 percent of the companies) are most communicated. On the other hand, the least communicated activity is the application of the good governance practices (31 percent of the companies).

Table 5

Communicating Social Responsibility Activities

\begin{tabular}{|l|c|c|c|c|c|c|c|c|}
\hline \multicolumn{1}{|c|}{ Type of firms } & Min & Max & Mean & Median & Mode & Std. Dev. & Skewness & Kurtosis \\
\hline Small & 0 & 8 & 2.56 & 2 & 0 & 2.31 & 1.38 \\
\hline Medium & 0 & 9 & 3.12 & 3 & 0 & 2.69 & 0.61 \\
\hline Large & 0 & 8 & 4.05 & 4 & 4 & 2.10 & -0.34 \\
\hline All firms & 0 & 9 & 3.38 & 3 & 4 & 2.48 & 0.16 \\
\hline
\end{tabular}

Significantly worse is the situation in the area of social responsibility (Table 5) where the number of activities communicated also grows with the size category of the companies. 10 out of 55 (18 percent) of the monitored companies do not communicate a single activity in this area. The most frequently communicated are 4 out of 11 activities assessed. From the point of view of specific activities, the chemical companies most frequently communicate education and development of employees (75 percent of the companies) and health and safety at work (73 percent of the companies). On the contrary, the least-communicated activity is the fight against mobbing and harassment (4 percent of the companies).

Communicating Environmental Responsibility Activities

Table 6

\begin{tabular}{|l|c|c|c|c|c|c|c|c|}
\hline \multicolumn{1}{|c|}{ Type of firms } & Min & Max & Mean & Median & Mode & Std. Dev. & Skewness & Kurtosis \\
\hline Small & 0 & 8 & 4.89 & 5 & 5 & 2.18 & -1.07 & 1.94 \\
\hline Medium & 0 & 8 & 4.64 & 6 & 6 & 2.48 & -0.33 & -1.27 \\
\hline Large & 2 & 8 & 5.52 & 6 & 6 & 1.50 & -0.46 & 0.14 \\
\hline All firms & 0 & 8 & 5.02 & 6 & 6 & 2.14 & -0.66 & -0.33 \\
\hline
\end{tabular}

On the contrary, the communication of CSR activities in the environmental field can be positively evaluated (Table 6). This confirms the idea that companies focus attention on communicating activities that are closely related to their social sensitivity. More than half of the companies communicate 6 of the 8 activities considered, the same number of activities are communicated most frequently. Even in this area, it is confirmed that large firms communicate CSR activities to a larger extent than SMEs. For a more detailed specification of particular activities, see Table 7 .

Communicating Individual Environmental Responsibility Activities

\begin{tabular}{|c|c|c|c|c|c|c|c|c|}
\hline \multirow{2}{*}{ Activities of environmental responsibility } & \multicolumn{2}{|c|}{ Small firms } & \multicolumn{2}{|c|}{ Medium firms } & \multicolumn{2}{|c|}{ Large firms } & \multicolumn{2}{|c|}{ All firms } \\
\hline & Freq. & $\%$ & Freq. & $\%$ & Freq. & $\%$ & Freq. & $\%$ \\
\hline Ensuring compliance with environmental legislation & 6 & $67 \%$ & 18 & $72 \%$ & 17 & $81 \%$ & 41 & $75 \%$ \\
\hline Saving energy and other resources & 7 & $78 \%$ & 16 & $64 \%$ & 14 & $67 \%$ & 37 & $67 \%$ \\
\hline Minimizing waste and promoting recycling & 7 & $78 \%$ & 17 & $68 \%$ & 17 & $81 \%$ & 41 & $75 \%$ \\
\hline Safe handling of hazardous substances & 3 & $33 \%$ & 9 & $36 \%$ & 10 & $48 \%$ & 22 & $40 \%$ \\
\hline Application of best available techniques & 4 & $44 \%$ & 11 & $44 \%$ & 12 & $57 \%$ & 27 & $49 \%$ \\
\hline Supporting resource conservation and biodiversity & 4 & $44 \%$ & 7 & $28 \%$ & 8 & $38 \%$ & 19 & $35 \%$ \\
\hline Preventing and correcting negative environmental impacts & 8 & $89 \%$ & 23 & $92 \%$ & 21 & $100 \%$ & 52 & $95 \%$ \\
\hline $\begin{array}{l}\text { Encouraging initiatives to promote a responsible approach to } \\
\text { the environment }\end{array}$ & 5 & $56 \%$ & 15 & $60 \%$ & 17 & $81 \%$ & 37 & $67 \%$ \\
\hline
\end{tabular}

Table 7 shows that the most communicated environmental activity is the prevention and remedy of the negative impacts of activities on the environment. On the other hand, the least communicated activity is the support for preserving resources and biodiversity.

Communicating Ethical Responsibility Activities

\begin{tabular}{|l|l|l|l|c|c|c|c|c|}
\hline \multicolumn{1}{|c|}{ Type of firms } & Min & Max & Mean & Median & Mode & Std. Dev. & Skewness & Kurtosis \\
\hline Small & 0 & 2 & 0.33 & 0 & 0 & 0.67 & 2.12 & 4.00 \\
\hline Medium & 0 & 4 & 0.40 & 0 & 0 & 0.89 & 3.00 & 10.11 \\
\hline Large & 0 & 3 & 0.71 & 0 & 0 & 0.88 & 1.09 & 0.40 \\
\hline All firms & 0 & 4 & 0.52 & 0 & 0 & 0.88 & 1.98 & 4.14 \\
\hline
\end{tabular}

The area of ethical responsibility (Table 8) can be described as the worst of them all from the point of view of the communication of chemical companies. 67 percent of the companies do not communicate any of the 8 activities under review. Most companies communicate the installation of a code of ethics (31 percent) and a line to report unethical behaviour (15 percent). Ethical reporting, ethical heroes, and the creation of a corporate ombudsman's office are not presented by either company. Even in the area of ethical responsibility, higher levels of communication are achieved by large companies. 
Communicating Philanthropic Responsibility Activities

\begin{tabular}{|l|c|c|c|c|c|c|c|c|}
\hline \multicolumn{1}{|c|}{ Type of firms } & Min & Max & Mean & Median & Mode & Std. Dev. & Skewness & Kurtosis \\
\hline Small & 0 & 3 & 0.67 & 0 & 0 & 1.05 & 1.53 & 1.26 \\
\hline Medium & 0 & 5 & 0.80 & 0 & 0 & 1.33 & 1.71 & 2.53 \\
\hline Large & 0 & 4 & 1.14 & 1 & 0 & 1.17 & 0.67 & -0.28 \\
\hline All firms & 0 & 5 & 0.91 & 0 & 0 & 1.24 & 1.24 & 0.93 \\
\hline
\end{tabular}

A high number of communicated activities are not achieved in the philanthropic area either (Table 9), although some companies (3) align the philanthropic responsibility with CSR, reporting its activities as the only CSR activities they carry out. 60 percent of the companies do not show any of the 5 philanthropic activities considered. Most companies communicate corporate giving (40 percent) and cooperation with non-profit organizations (35 percent). On the other hand, the support for donor activities of employees and for individual employee volunteering are the least communicated activities (in both cases 4 percent of the companies). Also, in the case of philanthropic responsibility activities, there is a greater range of communication by large companies compared to SMEs.

In conclusion, it is worth mentioning that, with exceptions, individual CSR activities on the websites of the monitored chemical companies are only mentioned, without being specified in detail and without their inputs, outputs, outcomes, impacts or developments in the field reported.

Based on the presented study it can be stated that the level of communication of CSR activities of chemical companies operating in the Czech Republic is low and corresponds to the generally low level of communication in this post-communist economy. Thus, the hypothesis H1 has been confirmed. This conclusion corresponds with the findings of, for example, Petera et al. (2014), who evaluated the level of CSR communication in the Czech Republic, Hąbek (2017), who evaluated the level of CSR communication in V4 countries and Horvath et al. (2017), who evaluated the maturity level of CSR communication in ten CEE countries and two WE countries, based on a content analysis of CSR reports.

The lowest level is achieved in the ethical and philanthropic areas. The highest level of communication is achieved in the economic area where activities dominate that are focused on customers as key stakeholders, and also in the environmental area, which is probably related to the source of social sensitivity of the chemical companies. Hence, the hypothesis $\mathrm{H} 2$ has been confirmed. The largest range of communicated environmental and economic activities was also documented by Petera et al. (2014) based on an analysis of CSR reports of the largest companies seated in the Czech Republic.

In all communicated areas of CSR (economic, social, environmental, ethical and philanthropic), a broader range of CSR communications was confirmed in large firms than in SMEs. Hence, the hypothesis H3 has been confirmed. For example, Hąbek (2017) also came to the same conclusion from the point of view of the V4 countries.

However, there was no difference in the range of communicated CSR activities between foreign-controlled companies and national private companies. Thus, the $\mathrm{H} 4$ hypothesis has been rejected. In the given context, it can be concluded that foreign-controlled companies adapt the scope of CSR communication to the practices applied in the Czech Republic. This is confirmed the findings of Chapple and Moon (2005) and Line and Braun (2007).

\section{Conclusions and Recommendations}

The presented study was developed in response to two closely related problems of CSR communication. The first is the limited knowledge base in this area where we see an interesting source of knowledge in companies of the so called high profile industries. The second is the generally declared low level of CSR communication achieved especially in post-communist countries, which needs to be examined in greater detail. Therefore, this paper focuses on the level of CSR communication of chemical industry companies in one of the post-communist countries - the Czech Republic. Both the overall level of CSR communication and the level of CSR communication in terms of ownership and size of companies as well as from the point of view of individual CSR areas are ed and evaluated. Particular attention is paid to CSR communication in the environmental field since it is owing to environmental risks that the chemical industry is considered to be a high profile industry. Based on the research carried out, literature review and the authors' own experience with CSR communication, recommendations are formulated to increase the level of CSR communication, which at the same time contribute to raising the level of knowledge in this field.

We can state that the level of communication of CSR activities of chemical companies operating in the Czech Republic is low. The lowest level is achieved in the ethical and philanthropic areas, while the highest level in the economic and environmental areas. Generally, there is a higher level of communication of large companies compared to SMEs. However, there are no differences in the level of CSR communication of chemical companies between national private companies and foreign-controlled companies.

Therefore, we can formulate recommendations for companies of high profile industries that can be used by companies of other industries as well. Moreover, these measures can be applied regardless of the country of operation of these companies. Measures to increase the level of CSR communication can be divided into two basic groups. The first group consists of regulatory measures adopted at the national level by respective governments. The second group consists of measures that should be implemented by the enterprises themselves.

As far as government regulatory measures are concerned, within the EU countries, in accordance with Directive 2014/95/EU, there is an obligation to communicate non-financial information for large undertakings which are public-interest entities exceeding 
on their balance sheet dates the criterion of the average number of 500 employees during the financial year. However, the Directive affects only a limited number of operators. At the national level, we can therefore recommend using the possibility of extending the scope of this Directive to a wider range of subjects, as has not been the case for the Czech Republic.

As far as the level of the enterprises is concerned, we can structure the proposed measures into the following groups:

- Rules and procedures for CSR communication. It is necessary to publish a broad range of detailed information on the activities developed, which will allow stakeholders to create a comprehensive view of the CSR activities being developed. We need to provide information not only about the inputs, outputs, outcomes and impacts of the activities being developed, but also about the development of the given indicators over time (KPMG, 2014). Only true and undistorted information may be published. To increase the credibility of the information communicated, it is recommended that they be verified by an independent auditor.

- Technical means of CSR communication. Printed annual reports or CSR reports are regarded as the traditional channels of CSR communication (Habek \& Brodny, 2017). However, in the context of ICT development, CSR channels enabling public access to information via the Internet are becoming increasingly important for communication. Therefore, we can recommend making these reports available on company websites. As far as web CSR communication is concerned, we can also recommend placing a "Corporate Social Responsibility" bookmark in the main menu of the companies' websites. This bookmark should include information on CSR activities divided by individual CSR areas, e.g. in line with the five concepts of CSR. Nowadays, we can neither ignore communication through social networks, such as Facebook, Twitter or Instagram.

- Content of CSR communication. The choice of communicated CSR activities can be based on international frameworks such as the OECD Guidelines for Multinational Enterprises, G4 Sustainability Reporting Guidelines or ISO 26000. Instructions for selecting communicated activities may also be found in the methodology presented in the article for communicating economic, social, environmental, ethical and philanthropic activities, offering a comprehensive view of implemented CSR activities. In case of high profile industries, special attention should be paid to those areas and CSR activities that are related to the increased sensitivity of corporate activities perceived by the company.
- Development of cooperation. An important role in the present knowledge society is played by a partnership that allows transfer of know-how. In order to increase the level of CSR communication, we can first of all consider the development of cooperation with non-profit organizations that promote responsible entrepreneurship. An example is the CSR Europe - European Business Network for Corporate Social Responsibility. In the Czech Republic, for example, it is the Business Leaders Forum or Business for Society. Another opportunity for the dissemination and sharing of knowledge and inspirational ideas is a partnership within professional associations. Last but not least, cooperation with universities can be considered a beneficial form of cooperation. It is advisable to work with academics as creators of new knowledge as well as university students.

- Implementation of examples of good practice. The level of CSR communication can also be increased by implementing measures that can be considered good practice examples. From the point of view of CSR communication, such practices are typically carried out by large companies. In the Czech Republic, mobile operator Vodafone Czech Republic a.s. can be considered as a significant bearer of good practice in the web CSR communication. Another source of inspirational ideas, especially in the field of philanthropic responsibility, is the websites of the power company CEZ, a.s., mobile operator T-Mobile Czech Republic a.s., banking institutions Československá obchodni banka, a.s. and Ceska sporitelna, a.s., tobacco company Philip Morris ČR a.s. or lottery company SAZKA a.s. A source of interesting ideas can also be the participation in prestigious competitions that appreciate various aspects of socially responsible business behaviour, such as the European CSR Awards, the International CSR Excellence Awards or the Best Employers. Participating in such competitions brings a valuable feedback and eventual appreciation improves the image of the company and can provide a competitive advantage.

A limiting factor of the presented paper is the fact that it deals with the issue of CSR communication from the perspective of a small post-communist economy - the Czech Republic. However, given the fact that the Czech Republic is a valid member of the EU, the presented study may represent a unique source of knowledge that can be used for comparisons within the EU countries. This and follow-up study can become an impulse not only for the adoption of appropriate government regulatory measures.

\section{References}

Aramayo Garcia, A., Arimany-Serrat, N., Uribe Salazar, C., \& Sabata Aliberch, A. (2016). Web Communication of CSR and Financial Performance: A Study of Catalan Meat Companies. Intangible Capital, 12(2), $391-419$. https://doi.org/10.3926/ic.590

Arnold, M. F. (2008). Non-financial performance metrics for corporate responsibility reporting revisited. Working Paper. Cranfield: A Doughty Centre for Corporate Responsibility. 
Baumann-Pauly, D., Wickert, C., Spence, L. J., \& Scherer, A. G. (2013). Organizing Corporate Social Responsibility in Small and Large Firms: Size Matters. Journal of Business Ethics, 115(4), 693-705. https://doi.org/10.1007/s10551013-1827-7

Birth, G., Illia, L., Lurati, F., \& Zamparini, A. (2008). Communicating CSR: The Practice in the Top 300 Companies in Switzerland. Corporate Communications: An International Journal, 13(2), 182-196. https://doi.org/10.1108/ 13563280810869604

Brammer, S., \& Millington, A. (2004). The Development of Corporate Charitable Contributions in the UK: A Stakeholder Analysis. Journal of Management Studies, 41(8), 1411-1434. https://doi.org/10.1111/j.1467-6486.2004.00480.x

Branco, M. C., \& Rodrigues, L. L. (2008). Factors Influencing Social Responsibility Disclosure by Portuguese Companies. Journal of Business Ethics, 83(4), 685-701. https://doi.org/10.1007/s10551-007-9658-Z

Capriotti, P., \& Moreno, A. (2007). Communicating Corporate Responsibility through Corporate Web Sites in Spain. Corporate Communications: An International Journal, 12(3), 221-237. https://doi.org/10.1108/13563280710776833

Carroll, A. B. (1979). A Three-Dimensional Conceptual Model of Corporate Performance. The Academy of Management Review, 4(4), 497-505. https://doi.org/10.2307/257850

Carroll, A. B. (1999). Corporate Social Responsibility - Evolution of a Definitional Construct. Business and Society, 38(3), 268-295. https://doi.org/10.1177/000765039903800303

Chambers, E., Chapple, W., Moon, J., \& Sullivan, M. (2003). CSR in Asia: A Seven Country Study of CSR Website Reporting. Nottingham, UK: International Centre for Corporate Social Responsibility.

Chapple, W., \& Moon, J. (2005). Corporate Social Responsibility (CSR) in Asia: A Seven-Country Study of CSR Web Site Reporting. Business \& Society, 44(4), 415-441. https://doi.org/10.1177/0007650305281658

Chaudhri, V., \& Wang, J. (2007). Communicating Corporate Social Responsibility on the Internet: A Case Study of the Top 100 Information Technology Companies in India. Management Communication Quarterly, 21(2), $232-247$. https://doi.org/10.1177/0893318907308746

COM(2011)206. Opinion of the European Economic and Social Committee on the Communication from the Commission to the European Parliament, the Council, the European Economic and Social Committee and the Committee of the Regions: Single Market Act - Twelve Levers to Boost Growth and Strengthen Confidence - "Working Together to Create New Growth".

COM(2011)681. Communication from the Commission to the European Parliament, the Council, the European Economic and Social Committee and the Committee of the Regions: A Renewed EU Strategy 2011-14 for Corporate Social Responsibility.

Darus, F., Arshad, R., Othman, S., \& Jusoff, K. (2009). Influence of Institutional Pressure and Ownership: Structure on Corporate Social Responsibility Disclosure. Interdisciplinary Journal of Contemporary Research in Business, 1(5), $123-150$.

Dincer, C., \& Dincer, B. (2010). An Investigation of Turkish Small and Medium-sized Enterprises Online CSR Communication. Social Responsibility Journal, 6(2), 197-207. https://doi.org/10.1108/17471111011051711

Du, S., Bhattacharya, C. B., \& Sen, S. (2010). Maximizing Business Returns to Corporate Social Responsibility (CSR): The Role of CSR Communication. International Journal of Management Reviews, 12(1), 8-19. https://doi.org/10.1111/j.1468-2370.2009.00276.x

Edgeman, R., \& Eskildsen, J. (2012). An Excellence Equation: (E3 Governance + 3E Strategy) $\Rightarrow$ 3P Performance. Journal of Positive Management, 3(1), 50-66. https://doi.org/10.12775/jpm.2012.004

Elo, S., Kaariainen, M., Kanste, O., Polkki, T., Utriainen, K., \& Kyngas, H. (2014). Qualitative Content Analysis: A Focus on Trustworthiness. SAGE Open, 4(1), 1-10. https://doi.org/10.1177/2158244014522633

Elo, S., \& Kyngas, H. (2008). The Qualitative Content Analysis Process. Journal of Advanced Nursing, 62(1), $107-115$. https://doi.org/10.1111/j.1365-2648.2007.04569.x

Esrock, S. L., \& Leichty, G. B. (1998). Social Responsibility and Corporate Web Pages: Self-presentation or AgendaSetting?. Public Relations Review, 24(3), 305-319. https://doi.org/10.1016/S0363-8111(99)80142-8

Gamerschlag, R., Moller, K., \& Verbeeten, F. (2011). Determinants of Voluntary CSR Disclosure: Empirical Evidence from Germany. Review of Managerial Science, 5(2/3), 233-262. https://doi.org/10.1007/s11846-010-0052-3

Golob, U., Podnar, K., Elving, W. J., Ellerup Nielsen, A., Thomsen, C., \& Schultz, F. (2013). CSR Communication: Quo Vadis? Corporate Communications: An International Journal, 18(2), 176-192. https://doi.org/10.1108/1356 3281311319472

Graafland, J. J., Eijffinger, S. C. W., Stoffele, N. C. G. M., Smid, H., \& Coldeweijer, A. M. (2002). Corporate social responsibility of Dutch companies: Benchmarking and transparency. Tilburg: Tilburg University.

Graafland, J., van de Ven, B., \& Stoffele, N. (2003). Strategies and Instruments for Organising CSR by Small and Large Businesses in the Netherlands. Journal of Business Ethics, 47(1), 45-60. https://doi.org/10.1023/A:1026240912016

Gray, R. (2007). Taking a Long View on What We Now Know About Social and Environmental Accountability and Reporting. Issues in Social and Environmental Accounting, 1(2), 169-198. https://doi.org/10.22164/isea.v1i2.13 
GRI. (2013). G4 Sustainability Reporting Guidelines. Available from Internet: https://www.globalreporting.org/ resourcelibrary/GRIG4-Part2-Implementation-Manual.pdf

Habek, P. (2017). CSR Reporting Practices in Visegrad Group Countries and the Quality of Disclosure. Sustainability, 9(12), 1-18. https://doi.org/10.3390/su9122322

Habek, P., \& Brodny, J. (2017). Corporate Social Responsibility Report - An Important Tool to Communicate with Stakeholders. In: 4th International Multidisciplinary Scientific Conference on Social Sciences \& Arts "SGEM 2017", 24-30 August, 2017, Albena, Bulgaria, 241-248.

Hackston, D., \& Milne, M. J. (1996). Some Determinants of Social and Environmental Disclosures in New Zealand Companies. Accounting, Auditing \& Accountability Journal, 9(1), 77-108. https://doi.org/10.1108/0 9513579610109987

Hoejmose, S., Brammer, S., \& Millington, A. (2013). An Empirical Examination of the Relationship between Business Strategy and Socially Responsible Supply Chain Management. International Journal of Operations \& Production Management, 33(5), 589-621. https://doi.org/10.1108/01443571311322733

Horvath, P., Putter, J. M., Dagiliene, L., Dimante, D., Haldma, T., Kochalski, C., ... Wagner, J. (2017). Status Quo and Future Development of Sustainability Reporting in Central and Eastern Europe. Journal of East European Management Studies, 22(2), 221-243. https://doi.org/10.5771/0949-6181-2017-2-221

Ihlen, O., Bartlett, J., \& May, S. (Eds.). (2014). The handbook of communication and corporate social responsibility. Chichester, UK: John Wiley \& Sons, Inc.

ISO. 2010. ISO 26000:2010 Guidance on Social Responsibility. Available from Internet: https://www.iso.org/obp/ ui/\#iso:std:iso:26000:ed-1:v1:en

Jelinkova, M., Munzarova, S., \& Lostakova, H. (2016). Internet CSR Presentation and its Importance for Increasing Corporate Reputation in the Area of Ferrous Metallurgy. In: 25th International Conference on Metallurgy and Materials "Metal 2016", 25-27 May, 2016, Brno, Czech Republic.

Jurisova, V., \& Durkova, K. (2012). CSR Communication and Its Impact on Corporate Image. Review of Applied SocioEconomic Research, 4(2), 145-149.

Knox, S., Maklan, S., \& French, P. (2005). Corporate Social Responsibility: Exploring Stakeholder Relationships and Programme Reporting across Leading FTSE Companies. Journal of Business Ethics, 61(1), 7-28. https://doi.org/10.1007/s10551-005-0303-4

Knudsen, J. S. (2011). Company Delistings from the UN Global Compact: Limited Business Demand or Domestic Governance Failure? Journal of Business Ethics, 103(3), 331-349. https://doi.org/10.1007/s10551-011-0875-0

Kolk, A. (2010). Trajectories of Sustainability Reporting by MNCs. Journal of World Business, 45(4), 367-374. https://doi.org/10.1016/j.jwb.2009.08.001

Konrad, A., Steurer, R., Langer, M. E., \& Martinuzzi, A. (2006). Empirical Findings on Business-Society Relations in Europe. Journal of Business Ethics, 63(1), 89-105. https://doi.org/10.1007/s10551-005-7055-z

Kostalova, J., \& Tetrevova, L. (2017). Supporting CSR Activities of Metallurgical Companies in the Czech Republic from EU Sources. In: 26th International Conference on Metallurgy and Materials "Metal 2017", 24-26 May, 2017, Brno, Czech Republic.

KPMG. (2015). Currents of Change: The KPMG Survey of Corporate Responsibility Reporting 2015. Available from Internet: https://home.kpmg.com/content/dam/kpmg/pdf/2015/12/KPMG-survey-of-CR-reporting-2015.pdf

KPMG. (2014). Sustainable Insight. Unlocking the Value of Social Investment. Available from Internet: https://assets.kpmg.com/content/dam/kpmg/pdf/2014/05/unlocking-value-social-investment.pdf

Krippendorff, K. (2004). Content analysis: An introduction to its methodology. London, UK: Sage Publications.

Laredo, P. (2007). Revisiting the Third Mission of Universities: Toward a Renewed Categorization of University Activities? Higher Education Policy, 20(4), 441-456. https://doi.org/10.1057/palgrave.hep.8300169

Levy, S. E., \& Park, S. Y. (2011). An Analysis of CSR Activities in the Lodging Industry. Journal of Hospitality and Tourism Management, 18(1), 147-154. https://doi.org/10.1375/jhtm.18.1.147

Line, M., \& Braun, R. (2007). Baseline Study on CSR Practices in the New EU Member States and Candidate Countries. Research Report. Available from Internet: http://docs.china-europa-forum.net/undpconference_26062007 _brochure.pdf

Maignan, I., \& Ferrell, O. C. (2004). Corporate Social Responsibility and Marketing: An Integrative Framework. Journal of the Academy of Marketing Science, 32(1), 3-19. https://doi.org/10.1177/0092070303258971

McWilliams, A., \& Siegel, D. (2001). Corporate Social Responsibility: A Theory of the Firm Perspective. Academy of Management Review, 26(1), 117-127. https://doi.org/10.5465/amr.2001.4011987

Montesinos, P., Carot, J. M., Martinez, J., \& Mora, F. (2008). Third Mission Ranking for World Class Universities: Beyond Teaching and Research. Higher Education in Europe, 33(2/3), 259-271. https://doi.org/10.10 80/03797720802254072 
Mousiolis, D. T., Zaridis, A. D., Karamanis, K., \& Rontogianni, A. (2015). Corporate Social Responsibility in SMEs and MNEs. The Different Strategic Decision Making. Procedia - Social and Behavioral Sciences, 175, 579-583. https://doi.org/10.1016/j.sbspro.2015.01.1240

Mulyadi, M. S., \& Anwar, Y. (2012). Impact of Corporate Social Responsibility toward Firm Value and Profitability. The Business Review, 19(2), 316-322.

Nielsen, A. E., \& Thomsen, C. (2009). CSR Communication in Small and Medium-sized Enterprises: A Study of the Attitudes and Beliefs of Middle Managers. Corporate Communications: An International Journal, 14(2), $176-189$. https://doi.org/10.1108/13563280910953852

OECD. (2011). OECD Guidelines for Multinational Enterprises. OECD Publishing. https://doi.org/10.1787/ 9789264115415-en

Pedersen, E. R. (2009). The Many and the Few: Rounding up the SMEs that Manage CSR in the Supply Chain. Supply Chain Management: An International Journal, 14(2), 109-116. https://doi.org/10.1108/13598540910941975

Peloza, J., \& Shang, J. (2011). How Can Corporate Social Responsibility Activities Create Value for Stakeholders? A Systematic Review. Journal of the Academy of Marketing Science, 39(1), 117-135. https://doi.org/10.1007/s11747010-0213-6

Petera, P., Wagner, J., \& Bouckova, M. (2014). An Empirical Investigation into CSR Reporting by the Largest Companies with their Seat in the Czech Republic. In: 22nd Interdisciplinary Information Management Talks "IDIMT-2014", 1012 September, 2014, Podebrady, Czech Republic, 321-329.

Reverte, C. (2008). Determinants of Corporate Social Responsibility Disclosure Ratings by Spanish Listed Firms. Journal of Business Ethics, 88(2), 351-366. https://doi.org/10.1007/s10551-008-9968-9

Roberts, R. W. (1992). Determinants of Corporate Social Responsibility Disclosure: An Application of Stakeholder Theory. Accounting Organizations and Society, 17(6), 595-612. https://doi.org/10.1016/0361-3682(92)90015-k

Said, R., Hj Zainuddin, Y., \& Haron, H. (2009). The Relationship between Corporate Social Responsibility Disclosure and Corporate Governance Characteristics in Malaysian Public Listed Companies. Social Responsibility Journal, 5(2), 212-226. https://doi.org/10.1108/17471110910964496

Schreier, M. (2012). Qualitative content analysis in practice. Thousand Oaks, CA: Sage.

Tagesson, T., Blank, V., Broberg, P., \& Collin, S. (2009). What Explains the Extent and Content of Social and Environmental Disclosures on Corporate Websites: A Study of Social and Environmental Reporting in Swedish Listed Corporations? Corporate Social Responsibility and Environmental Management, 16(6), 352-364. https://doi.org/10.1002/csr.194

Takano, K. (2013). Communicating CSR: Case Study of Japanese Food Industry. International Journal of Business and Management 8(9), 111-121. https://doi.org/10.5539/ijbm.v8n9p111

Tamm, K., Eamets, R., \& Motsmees, P. (2010). Relationship between corporate social responsibility and job satisfaction: The case of Baltic countries. Tartu: University of Tartu.

Tetrevova, L. (2011). Corporate Social Responsibility in the Czech Gambling Industry. Economics and Management, $16(1), 612-620$.

Tetrevova, L., Vavra, J., Bednarikova, M., Munzarova, S., \& Kostalova, J. (2017). Corporate social responsibility in socially sensitive sectors (in Czech). Prague: Grada Publishing.

van Marrewijk, M., \& Were, M. (2003). Multiple Levels of Corporate Sustainability. Journal of Business Ethics, 44(2), 107-119. https://doi.org/10.1023/a:1023383229086

van Wensen, K., Broer, W., Klein, J., \& Knopf, J. (2011). The State of Play in Sustainability Reporting in the EU. Research Study. Available from Internet: http://t.upj.de/fileadmin/user_upload/MAIN-dateien/Themen/Trends/ eu_stateofplay_2011.pdf

Vlckova, V. (2011). Reasons of Insufficient Cooperation in Information Sharing within Czech Entrepreneurial Environment and its Impact on Supply Chain. In: 20th International Conference on Metallurgy and Materials "Metal 2011", 18-20 May, 2011, Brno, Czech Republic.

The article has been reviewed.

Received in October, 2017; accepted in October, 2018. 